Jurnal Health Sains: p-ISSN : 2723-4339 e-ISSN : 2548-1398

Vol. 2, No. 2, Februari 2021

\title{
HUBUNGAN STATUS GIZI DAN ANEMIA DENGAN KEJADIAN BAYI BERAT BADAN LAHIR RENDAH DI RUMAH SAKIT DUSTIRA CIMAHI TAHUN 2018
}

\section{Endah Sri Lestari}

Akademi Keperawatan Rumah Sakit Dustira, Cimahi, Jawa Barat, Indonesia

Email: lestarisarmuji@gmail.com

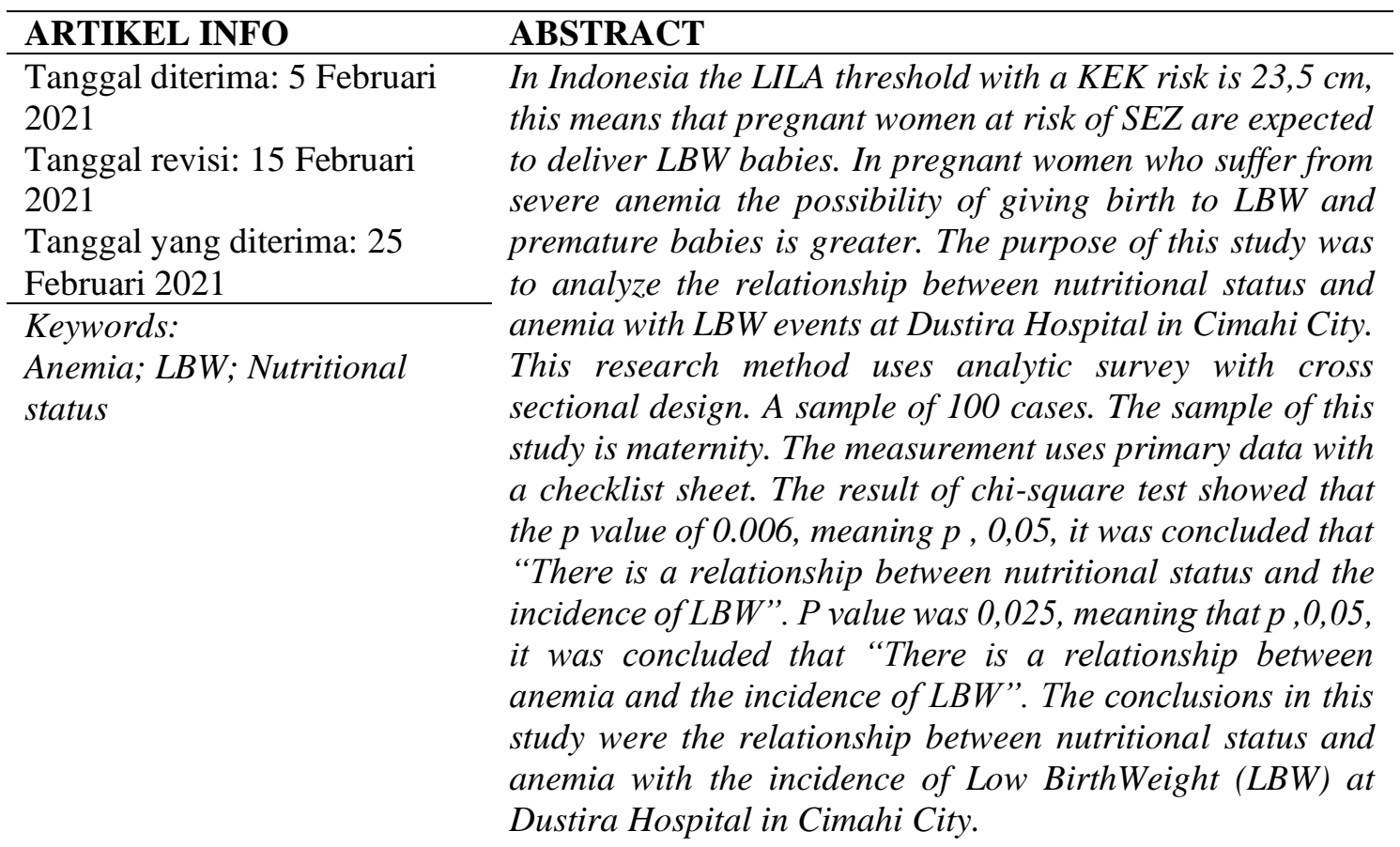

Kata Kunci:

ABSTRAK

Di Indonesia batas ambang LILA dengan resiko KEK adalah 23,5 cm hal ini berarti ibu hamil dengan resiko KEK di perkirakan akan melahirkan bayi BBLR. Pada ibu hamil yang menderita anemia berat kemungkinan melahirkan bayi BBLR dan premature lebih besar. Tujuan Penelitian ini yaitu untuk menganalisa hubungan Status gizi dan Anemia dengan kejadian BBLR di Rumah sakit Dustira Kota Cimahi. Metode penelitian ini menggunakan survey analitik dengan rancangan Cross sectional. Sampel kasus sebanyak 100 orang. Sampel penelitian ini yaitu ibu bersalin. Pengukuran menggunakan data primer dengan lembar cheklis. Hasil uji chi-square menunjukan bahwa nilai $\mathrm{p}$ sebesar 0,006 , berarti $\mathrm{p}<0,05$ maka disimpulkan bahwa "Terdapat hubungan antara status gizi dengan kejadian BBLR". Nilai p sebesar 0,025 , berarti $p<0,05$ maka disimpulkan bahwa "Terdapat hubungan antara anemia dengan kejadian Berat Badan lahir rendah (BBLR) di Rumah Sakit dustira Kota Cimahi. 
Coresponden Author:

Email: lestarisarmuji@gmail.com Artikel dengan akses terbuka dibawah lisensi

\section{Pendahuluan}

Angka Kematian Bayi (AKB) adalah jumlah kematian bayi dalam usia 28 hari pertama kehidupan per 1000 kelahiran hidup. Angka Kematian Bayi Menurut WHO (World Helth Organization) (2015) Pada Negara ASEAN (Association of South East Asia Nations) seperti Singapura 3 per 1000 kelahiran hidup, Malaysia 5,5 per 1000 kelahiran hidup, Thailand 17 per 1000 kelahiran hidup, Vietnam 18 per 1000 kelahiran hidup, dan Indonesia 27 per 1000 kelahiran hidup.

Jumlah berat bayi lahir rendah (BBLR) di Indonesia masih cukup tinggi. Data WHO mencatat Indonesia berada di peringkat Sembilan dunia dengan persentase BBLR lebih dari 15,5 persen dari kelahiran bayi setiap tahunnya.

Berdasarkan hasil Survei Demografi dan Kesehatan Indonesia (SDKI) tahun 2012, Angka Kematian Neonatus (AKN) pada tahun 2012 sebesar 19 per 1000 kelahiran hidup. Angka ini sama dengan AKN berdasarkan SDKI tahun 2007 dan hanya menurun 1 poin disbanding SDKI tahun 2002-2003 yaitu 20 per 1000 kelahiran hidup (Roeslie \& Bachtiar, 2018).

Hasil Survei Penduduk Antar Sensus (SUPAS) 2015 menunjukan AKB sebesar 22,23 per 1000 kelahiran hidup, yang artinya sudah mencapai target MDG 2015 sebesar 23 per 1000 kelahiran hidup. Begitu pula dengan angka kematian balita (AKABA) hasil SUPAS 2015 sebesar 26,29 per 1000 kelahiran hidup, juga memenuhi target MDG 2015 sebesar 32 per 1000 kelahiran hidup (Roeslie \& Bachtiar, 2018).

Hasil Pemantauan Status Gizi (PSG) 2016 mendapatkan hanya 40,2\% ibu hamil 162 mendapatkan TTD minimal 90 tablet lebih rendah dari target nasional tahun 2016 sebesar 85\%. (Dinas Kesehatan Indonesia 2016) Persentase BBLR tahun 2013 (10,2\%) lebih rendah dari tahun $2010(11,1 \%)$. Persentase BBLR tertinggi terdapat di provinsi Sulawesi Tengah $(16,9 \%)$ dan terendah di Sumatera Utara (7,2\%) (Dasar, 2013).

Menurut kelompok umur, persentase BBLR tidak menunjukan kecenderungan yang jelas. Persentasi BBLR pada perempuan $(11,2 \%)$ lebih tinggi daripada laki - laki $(9,2 \%)$, namun persentase berat lahir $\geq 4000$ gram pada laki - laki (5,6\%) lebih tinggi dibandingkan perempuan (3,9\%) (Dasar, 2013).

Menurut pendidikan dan kuintil indek kepemilikan terlihat adanya kecenderungan semakin tinggi pendidikan dan kuintil indeks kepemilikan, semakin rendah prevalensi BBLR. Menurut jenis pekerjaan, persentase BBLR tertinggi pada anak balita dengan kepala rumah tangga yang tidak bekerja $(11,6 \%)$, sedangkan persentase terendah pada kelompok pekerjaan pegawai $(8,3 \%)$. Persentas BBLR di pedesaan $(11,2 \%)$ lebih tinggi dari perkotaan $(9,4 \%)$.(Riskesdas, 2013).

Angka kematiaan bayi (AKB) atau Infan Mortality Rate (IMR) merupakan indikator yang sangat sensitif terhadap upaya pelayanan Kesehatan terutama berhubungan dengan bayi baru lahir perinatal dan neonatal. (Dinas Kesehatan Jawa Barat 2015) AKB mengambarkan besarnya resiko kematian bayi (< 1 tahun) dalam 1000 kelahiran hidup. Berdasarkan kesepakat internasional AKB merupakan indikator yang menggunakan konsep rate, meskipun dalam kenyataannya hanya ratio. Berdasarkan publikasi BPS, AKB Jurnal Health Sains Vol. 2, No. 2, Februari 2021 
provinsi Jawa Barat sejak tahun 2003 sampai dengan tahun 2009 cenderung mengalami penurunan. Selama periode 2003 s/d 2009 AKB berhasil diturunkan sebesar 6.5 poin (range 42.5 - 36/1000 kelahiran hidup). Berarti di Provinsi Jawa Barat rata - rata AKB turun sebesar 1 poin setiap tahunnya (Sucipto et al., 2015).

Untuk AKB 2013, BPS melakukan publikasi berdasarkan SDKI 2012, dimana Provinsi Jawa Barat mempunyai AKB sebesar 30/1.000 kelahiran hidup. Dibandingkan AKB 2009, maka terjadi penurunan sebesar 6 poin, yaitu dari 36/1.000 kelahiran hidup menjadi 30/1.000 kelahiran hidup. Berdasarkan pencatatan dan pelaporan, di Provinsi Jawa Barat tahun 2015 terdapat 4019 bayi meninggal meningkat 82 orang disbanding tahun 2014 yang tercatat 3937 kematian bayi. Range pelaporan bayi periode 2009 s/d 2015 antara 3.982 - 5719 kematian bayi, dengan rata - rata 4.679/tahun (Sucipto et al., 2015).

Proporsi kematian bayi pada tahun 2016 sebesar 3,93/1000 kelahiran hidup, menurun 0,16 poin disbanding tahun 2015 sebesar 4,09/1000 kelahiran hidup. Proporsi kematian bayi berasal dari bayi usia 028 hari (Neonatal) sebesar $84,63 \%$ atau 3,32/1000 kelahiran hidup (Sucipto et al., 2015).

Selama ini upaya penangulangan anemia gizi di fokuskan ke sasaran ibu hamil dengan suplemen besi. Cakupan pemberian tablet besi (Fe) pada ibu hamil dengan mendapatkan 90 tablet Besi (Fe3) pada tahun 2014 sebesar 97,57\%, angka ini sudah mencapai target $(90 \%)$, apabila cakupan ini dibandingkan tahun $2010 \quad(82,09 \%)$ mengalami kenaikan sebesar 15,48\%. (Dinas Kesehatan Jawa Barat 2014).

Persentase BBLR Antara 0,1\% - 5,7\%, dan BBLR Jawa Barat sebesar 2,2\% dari jumlah bayi yang ditimbang, jumlah tertinggi BBLR terdapat di Kab. Kuningan (5,7\%), dan terendah di Kota Bogor (0,3\%). (Dinas Kesehatan Jawa Barat 2016).
Kematian neonatal didefinisikan sebagai kematian bayi lahir hidup yang terjadi pada masa kelahiran sampai 28 hari setelah hari kelahiran (bayi umur 1 bulan). Angka kematian neonatal di Kota Cimahi pada tahun 2014 sebesar 60 kematian per 10.539 kelahiran hidup (5,69/1.000). Adapun proporsi kematian neonatal laki - laki lebih banyak sebesar 31 kasus (52\%) dari perempuan sebesar 29 kasus (48\%). (Dinas Kesehatan Kota Cimahi 2014).

Penyebab langsung kematian bayi paling banyak tahun 2013 yaitu BBLR dan Aspiksia, selain itu kematian bayi juga disebabkan oleh Diare, kelainan kongenital, pneumonia, ISPA, TB Paru dan Ikterus. (Dinas Kesehatan Kota Cimahi 2014)

Jumlah kematian anak di Kota Cimahi tahun 2014 yang dilaporkan berjumlah 82 kasus, yang terdiri dari kematian neonatal 60 kasus $(73,17 \%)$, kematian bayi 18 kasus $(21,95 \%)$, dan 4 kasus $(4,88 \%)$ kematian balita. (Dinas Kesehatan Kota Cimahi 2014).

Banyak faktor yang dikaitkan dengan kematian bayi. Kematian bayi di kota Cimahi yang dilaporkan berjumlah 18 kematian per 10.539 kelahiran hidup atau 1,71/1.000 kelahiran hidup. Angka tersebut telah memenuhi indicator kinerja kota Cimahi sebesar <29,80/1.000 KH. Angka kematian bayi perempuan lebih banyak sebesar 10 kasus (56\%) daripada anak laki - laki sebanyak 8 kasus (44\%). (Dinas Kesehatan Kota Cimahi 2014).

Adapun penyebab kematian bayi di kota Cimahi adalah bayi berat lahir rendah (BBLR) sebesar 18 kasus, Asfiksia sebesar 26 kasus, Aspirasi sebesar 1 kasus, Ikterus sebesar 2 kasus, ISPA sebanyak 1 kasus, Disentri sebanyak 2 kasus, gangguan saluran cerna sebesar 1 kasus, kelainan kongenital sebesar 12 kasus, infeksi sebesar 4 kasus, dan lainnya sebesar 11 kasus. Persentase BBLR di kota Cimahi yaitu 3,2\%. (Dinas Kesehatan Kota Cimahi 2014). 
Menurut penelitian Nur"aini Siti Alifah, Pujiastuti Wahyu, Widiatiningsih Sri di Puskesmas Garung Kabupaten Wonosobo (2013) menunjukkan bahwa ada berbagai faktor secara teoritis yang mempengaruhi berat badan bayi baru lahir di samping faktor genetris, yaitu status gizi janin, yang ditentukan antara lain oleh status gizi ibu pada waktu melahirkan dan keadaan ini di pengaruhi pula oleh status gizi ibu pada waktu konsepsi yang di pengaruhi oleh keadaan sosial dan ekonomi, keadaan kesehatan dan gizi ibu, jarak kehamilan jika yang di kandung bukan anak pertama (Amareta, 2015). Cara yang diganakan untuk mengetahui status gizi ibu hamil antara lain memantau pertambahan berat selama hamil, mengukur Lingkar Lengan Atas (LILA), sedangkan pengukuran $\mathrm{Hb}$ untuk mengetahui kondisi ibu apakah menderita anemia gizi (Sibagariang et al., 2010).

Menurut penelitian (Nurbaiti, 2016) di Kabupaten Aceh Besar menunjukkan bahwa ibu hamil dengan masalah gizi dan kesehatan dan keselamatan ibu dan bayi serta kualitas bayi yang akan dilahirkan. Ibu hamil yang menderita Kekurangan Energi Kronis (KEK) dapat menimbulkan risiko terhadap bayi yang dilahirkan antara lain dapat mengakibatkan terjadinya kematian janin, kelahiran prematur, lahir cacat dan Bayi Berat Lahir Rendah (BBLR) bahkan kematian bayi. KEK pada ibu hamil ditandai dengan batas Lingkar Lengan Atas (LILA) kurang dari 23,5 Cm. Ibu dengan keadaan KEK mempunyai risiko 2,0087 kali untuk melahirkan bayi BBLR dibanding dengan ibu yang memiliki ukuran LILA lebih dari $23 \mathrm{~cm} 3$. Selain itu ibu yang menderita anemia, secara signifikan meningkatkan risiko kelahiran prematur sesuai derajat keparahan Anemia dan pada ibu yang menderita Anemia berat mempunyai risiko 3,8 kali untuk melahirkan bayi dengan BBLR.

Menurut penelitian (Indrawati \& Suratini, 2015) di Kabupaten Sleman menunjukkan bahwa masalah gizi merupakan salah satu penyebab kematian ibu dan anak secara tidak langsung yang sebenamva masih dapat dicegah. Rendahnya status gizi ibu hamil selama kehamilan dapat mengakibatkan berbagai dampak tidak baik bagi ibu hamil dan bayi, diantaranya adalah bayi lahir dengan Berat Badan Lahir Rendah (BBLR). Bayi dengan BBLR mempunyai peluang meninggal 10-20 kali lebih besar dari pada bayi yang lahir dengan berat lahir cukup oleh karena itu, perlu adanya deteksi dini dalam kehamilan yang dapat mencerminkan pertumbuhan janin melalui penilaian status gizi ibu hamil. (Chairunita et al., 2006).

Berdasarkan studi pendahuluan pada tanggal 23 Februari 2018 yang dilakukan di Rumah Sakit Dustira Kota Cimahi di dapatkan bahwa masih banyak sekali ibu yang melahirkan bayi BBLR yaitu sekitar 6,1\% pada tahun 2015, 5,5\% pada tahun 2016 dan $8,3 \%$ pada tahun 2017 , ada penurunan pada tahun 2015 ke 2016 tetapi meningkat pada tahun 2017 sebanyak 2,8\% bayi yang mengalami BBLR. Salah satu penyebabnya adalah gizi saat hamil yang kurang (KEK), Anemia, Jarak hamil dan bersalin terlalu dekat, Penyakit menahun ibu dan lain sebagainya. Pada saat studi pendahuan di Rumah Sakit Dustira terdapat 130 bayi dari 1560 persalinan pada tahun 2017 yang mengalami BBLR.

Berdasarkan latar belakang masalah diatas, maka peneliti tertarik untuk mengadakan penelitian dan dituangkan dalam bentuk Karya Tulis Ilmiah dengan judul "Hubungan Status Gizi dan Anemia dengan kejadian Berat Badan Lahir Rendah di Rumah Sakit Dustira Kota Cimahi 2018".

\section{Metode Penelitian}

Penelitian ini menggunakan metode penelitian studi survei analitik dengan rancangan cross sectional. Metode penelitian analitik adalah survei atau penelitian yang mencoba menggali bagaimana dan mengapa fenomena kesehatan itu terjadi. Kemudian 
melakukan analisis dinamika korelasi antara fenomena atau antara faktor risiko dengan faktor efek. Yang di maksud faktor efek adalah suatu akibat dari adanya faktor risiko, sedangkan faktor risiko adalah suatu fenomena yang mengakibatkan terjadinya efek (pengaruh) (Yuliati et al., 2014).

Rancangan penelitian cross sectional adalah suatu penelitian untuk mempelajari dinamika kolerasi antara faktor risiko dengan efek, dengan cara pendekatan, observasi atau pengumpulan data sekaligus pada suatu saat (point time approach). Artinya, tiap subjek penelitian hanya diobservasi sekali saja dan pengukuran dilakukan terhadap status karakteristik atau subjek pada saat pemeriksaan (Yuliati et al., 2014).

\section{Hasil dan Pembahasan}

Hasil penelitian ini disajikan dalam bentuk analisis univariat dan bivariat. Sampel dalam penelitian ini ibu bersalin yang memiliki buku KIA di rumah sakit dustira tingkat II kota eimahi dengan jumlah responden 100 orang dan dilakukan penelitian pada tanggal 24 april 2018. Setelah dilakukan pengolahan data, didapatkan hasil sebagai berikut:

1. Analisi Univariat

Tabel 4.1

Distribusi Frekuensi Status Gizi Ibu Bersalin Di Rumah Sakit Dustira Tingkat

II Kota Cimahi Tahun 2018

\begin{tabular}{lcc}
\hline Status Gizi & Frekuensi & Persentase \% \\
\hline KEK & 46 & 46,0 \\
\hline Tidak KEK & 54 & 54,0 \\
\hline Total & 100 & 100,0 \\
\hline
\end{tabular}

Berdasarkan tabel 4.1 menunjukan bahwa Sebagian besar ibu bersalin yang tidak mengalami KEK sebesar $54 \%$.

Tabel 4.2
Distribusi Frekuensi Anemia Ibu Bersalin Di Rumah Sakit Dustira Tingkat II Kota Cimahi 2018

\begin{tabular}{ccc}
\hline Anemia & Frekuensi & Persentase \% \\
\hline Anemia & 49 & 49,0 \\
\hline Tidak Anemia & 51 & 51,0 \\
\hline Total & 100 & 100,0 \\
\hline
\end{tabular}

Berdasarkan tabel 4.2 menunjukan bahwa Sebagian besar ibu bersalin yang tidak mengalami anemia sebesar $51 \%$.

Tabel 4.3

Distribusi Frekuensi BBLR Di Rumah Sakit Dustira Tingkat II Kota Cimahi Tahun 2018

\begin{tabular}{ccc}
\hline BBLR & Frekuensi & Persentase \% \\
\hline BBLR & 56 & 56,0 \\
\hline Tidak & 44 & 44,0 \\
BBLR & & \\
\hline Total & 100 & 100.0 \\
\hline
\end{tabular}

Berdasarkan tabel 4.3 menunjukan bahwa Sebagian besar ibu bersalin mempunyai bayi BBLR sebesar $56 \%$.

2. Analisis Bivariat

Hasil analisis ini bertujuan untuk mengetahui adanya Hubungan Status Gizi dengan BBLR dan Hubungan Anemia dengan BBLR di Rumah Sakit Dustira Tahun 2018. Analisis bivariat dalam bentuk penelitian ini sebagai berikut:

\section{Tabel 4.4}

Hubungan Status Gizi Dengan Berat Badan Lahir Rendah di Rumah Sakit Dustira Tingkat II Kota Cimahi Tahun 2018

\begin{tabular}{|c|c|c|c|c|c|c|c|}
\hline & BBLR & $\%$ & $\begin{array}{l}\text { Tidak } \\
\text { BBLR }\end{array}$ & $\%$ & Total & $\%$ & $\begin{array}{c}\text { p- } \\
\text { value }\end{array}$ \\
\hline Anemia & 19 & 41,3 & 27 & 58,7 & 46 & 100,0 & \multirow{4}{*}{0,006} \\
\hline Tidak & 37 & 65,5 & 17 & 31,5 & 54 & 100,0 & \\
\hline Anemia & & & & & & & \\
\hline Total & 56 & 56,0 & 44 & 44,0 & 100 & 100,0 & \\
\hline
\end{tabular}

Berdasarkan hasil pada tabel 4.4 menunjukkan bahwa untuk mengetahui ada 
tidaknya hubungan yang signifikan antara status gizi ibu bersalin dengan kejadian BBLR dapat diketahui dari hasil uji statistik chisquare nilai $\mathrm{p}$ (signifikasi) yang didapatkan adalah 0,006 yang berarti $\mathrm{p}<0,05$ maka Ho ditolak sehingga dapat disimpulkan bahwa "Terdapat hubungan antara status gizi ibu bersalin dengan kejadian BBLR di Rumah Sakit Dustira Tingkat II Kota Cimahi tahun 2018".

\section{Tabel 4.5}

\begin{tabular}{|c|c|c|c|c|c|c|c|}
\hline \multicolumn{8}{|c|}{$\begin{array}{l}\text { Hubungan Anemia Dengan Berat Badan } \\
\text { Lahir Rendah di Rumah Sakit Dustira } \\
\text { Tingkat II Kota Cimahi Tahun } 2018\end{array}$} \\
\hline & BBLR & $\%$ & $\begin{array}{l}\text { Tidak } \\
\text { BBLR }\end{array}$ & $\%$ & Total & $\%$ & 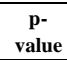 \\
\hline emia & 33 & 67,3 & 16 & 32,7 & 49 & $1 \mathbf{1 0 0 , 0}$ & \\
\hline $\begin{array}{l}\text { Tidak } \\
\text { Inemia }\end{array}$ & 23 & 45,1 & 28 & 54,9 & 51 & 100,0 & \\
\hline Total & 56 & 56,0 & 44 & 44,00 & \begin{tabular}{ll|l}
100 \\
\end{tabular} & \begin{tabular}{ll|l}
100,0 \\
\end{tabular} & \\
\hline
\end{tabular}

Berdasarkan hasil pada tabel 4.5 menunjukkan bahwa untuk mengetahui ada tidaknya hubungan yang signifikan antara anemia pada ibu bersalin dengan kejadian BBLR dapat diketahui dari hasil uji statistik chi-square nilai $\mathrm{p}$ (signifikasi) yang didapatkan adalah 0,025 yang berarti $\mathrm{p}<0,05$ maka Ho ditolak sehingga dapat disimpulkan bahwa "Terdapat hubungan antara anemia pada ibu bersalin dengan kejadian BBLR di Rumah Sakit Dustira Tingkat II Kota Cimahi tahun 2018".

\section{Pembahasan}

\section{Status Gizi Pada Ibu Hamil}

Berdasarkan hasil penelitian menunjukkan bahwa sebagian besar ibu bersalin yang tidak mengalami KEK sebesar 54 orang (54\%) dan hampir sebagian ibu bersalin yang mengalami KEK sebesar 46 orang (46\%). Program di Rumah Sakit Dustira Tingkat II Kota Cimahi yaitu pemeriksaan LILA dan penyuluhan tentang gizi ibu hamil itu sangat penting untuk pertumbuhan dan perkembangan janin juga penting untuk ibunya.

Kekurangan gizi pada ibu hamil dapat mempengaruh proses pertumbuhan janin dan dapat menimbulkan keguguran, bayi lahir mati, kematian neonatal, cacat bawaan, anemia pada bayi, asfiksia intrapartum (mati dalam kandungan), lahir dengan berat badan lahir rendah (BBLR) (Sukarni, 2013).

Gizi kurang pada ibu hamil bisa menyebabkan (1) Terhadap ibu: Gizi kurang pada ibu hamil dapat menyebabkan risiko dan komplikasi pada ibu antara lain: anemia, perdarahan, berat badan ibu tidak bertambah secara normal, dan terkena penyakit infeksi. (2) Terhadap persalinan: Pengaruh gizi kurang terhadap proses persalinan dapat mengakibatkan persalinan sulit atau lama, persalinan sebelum waktunya (premature), pendarahan setelah persalinan, serta persalinan dengan operasi cenderung meningkat. (3) Terhadap janin: Kekurangan gizi pada ibu hamil dapat mempengaruh proses pertumbuhan janin dan dapat menimbulkan keguguran, bayi lahir mati, kematian neonatal, cacat bawaan, anemia pada bayi, asfiksia intra partum (mati dalam kandungan), lahir dengan berat badan lahir rendah (BBLR) (Sukarni, 2013).

Status gizi adalah suatu keadaan tubuh yang diakibatkan oleh keseimbangan antara asupan gizi dengan kebutuhan. Keseimbangan tersebut dapat dilihat dari variabel pertumbuhan, yaitu berat badan, tinggi badan, tinggi badan atau panjang badan, lingkar kepala, lingkar lengan, dan panjang tungkai. Jika keseimbangan tadi terganggu, misalnya pengeluaran energi dan protein lebih banvak dibandingkan pemasukan maka akan terjadi kekurangan energi protein, 
dan jika berlangsung lama akan timbul masalah yang dikenal dengan KEP berat atau gizi buruk (Marmi et al., 2015).

Hal ini sejalan dengan penelitian yang dilakukan oleh Indrawati Siti tahun 2015 di wilayah Puskesmas Minggir Kabupaten Sleman, yang menyatakan bahwa status gizi ibu hamil sangat mempengaruhi pertumbuhan janin yang sedang dikandung. Bila status gizi ibu normal pada masa kehamilan maka kemungkinan besar melahirkan bayi yang sehat, cukup bulan dengan berat badan normal. Kualitas bayi yang dilahirkan sangat tergantung pada keadaan gizi ibu selama hamil.

2. Anemia Pada Ibu Hamil

Berdasarkan hasil penelitian menunjukkan bahwa sebagian besar ibu bersaiin yang tidak mengalami kejadian anemia sebesar 51 orang (51\%) dan hampir sebagian ibu bersaiin yang mengalami kejadian anemia sebesar 49 orang (49\%).

Program di Rumah Sakit Dustira tingkat Kota Cimahi yaitu pemberian tablet $\mathrm{Fe} 90$ tablet supaya tidak perdarahan pada saat kehamilan maupun persalinan. Bahaya anemia terhadap janin. Sekalipun tampaknya janin mampu menyerap berbagai kebutuhan dari ibunya, tetapi dengan anemia akan mengurangi kemampuan metabolisme tubuh sehingga mengganggu pertumbuhan dan perkembangan janin dalam rahim akibat anemia dapat terjadi anemia dalam bentuk: abortus, kematian intauterin, persalinan prematuritas tinggi, berat badan lahir rendah, kelahiran dengan anemia, dapat terjadi cacat bawaan, bayi mudah mendapat infeksi sampai kematian perinatal, dan inteligensia rendah (Manuaba, 2013).

Penyebab anemia tersering adalah defisiensi zat-zat nutrisi. Sering kali defisiensinya bersifat multipel dengan manifestasi klinik yang disertai infeksi, gizi buruk, atau kelainan herediter seperti hemoglobinopati. Namun, penyebab mendasar anemia nutrisional meliputi asupan yang tidak cukup, absorbsi yang tidak adekuat, bertambahnya zat gizi yang hilang, kebutuhan yang berlebihan, dan kurangnya utilisasi nutrisi hemopoietik. Sekitar $75 \%$ anemia dalam kehamilan disebabkan oleh defisiensi besi yang memperlihatkan gambaran eritrosit mikrositik hipokrom pada apusan darah tepi. Penyebab tersering kedua adalah anemia megaloblastik yang dapat disebabkan oleh defisiensi asam folat dan defisiensi vitamin B12. Penyebab anemia lainnya yang jarang ditemui antara lain adalah hemoglobinopati, proses inflamasi, toksisitas zat kimia, dan keganasan (Saifudin, 2014).

Anemia pada kehamilan adalah anemia karena kekurangan zat besi. Menurut WHO kejadian anemia kehamilan berkisar antara $20 \%$ sampai dengan 89\% dengan menetapkan $\mathrm{Hb} 11$ gr\% sebagai dasarnya. $\mathrm{Hb}$ 9-10 gr\% disebut anemia ringan. $\mathrm{Hb} \quad 7-8$ gr\% disebut anemia sedang. $\mathrm{Hb}<7 \mathrm{gr} \%$ disebut anemia berat (Manuaba, 2013).

Hal ini sejalan dengan penelitian yang dilakukan oleh Liesmayani Elvi Era di RSU (Silalahi et al., 2015), bahwa anemia dalam kehamilan dapat mempengaruhi kesejahteraan ibu, baik dalam kehamilan, persalinan maupun dalam masa nifas terutama juga pada bayi yang akan dilahirkan di antaranya dapat mengalami BBLR dan berisiko komplikasi yang serius.

3. Berat Badan Lahir Rendah

Berdasarkan hasil peuelitian menunjukkan bahwa sebagian besar ibu bersalin yang mempunyai bayi BBLR sebesar 56 orang (56\%) dan hampir 
sebagian ibu bersalin yang mempunyai bayi tidak BBLR sebesar 44 orang (44\%). Program di Rumah Sakit Dustira Tingkat II Kota Cimahi yaitu melakukan deteksi dini pada saat kehamilan dan jika lahir terjadi BBLR maka akan dilakukan langkah awal penanganan dan perawatan bayi dengan BBLR.

Di Indonesia batas ambang LILA dengan risiko KEK adalah $23,5 \mathrm{~cm}$ hal ini berarti ibu hamil dengan risiko KEK di perkirakan akan melahirkan bayi BBLR. Bila bayi lahir dengan berat badan lahir rendah (BBLR) akan mempunyai risiko kematian, gizi kurang, gangguar. pertumbuhan, dan gangguan perkembangan anak. Untuk mencegah risiko KEK pada ibu hamil sebelum kehamilan wanita usia subur sudah harus mempunyai gizi yang baik, misalnya dengan LILA tidak kurang dari $23,5 \mathrm{~cm}$. Apabila LILA ibu sebelum hamil kurang dari angka tersebut, sebaiknya kehamilan ditunda sehingga tidak berisiko melahirkan BBLR (Sukarni, 2013).

BBLR tidak hanya disebabkan oleh anemia dan KEK saja tetapi ada faktor lain yang bisa menyebabkan BBLR seperti Paritas/jumlah anak yang terlalu banyak, Jarak kehamilan dan bersalin terialu dekat, usia yang terlalu muda $<20$ tahun atau terlalu tua $>35$ tahun, Ibu hamil yang merokok dan penyalahgunaan obat, Penyakit menahun ibu seperti: hipertensi, jantung, gangguan pembuluh darah (perokok), Ibu yang pernah melahirkan bayi prematur/BBLR sebelumnya (Maryunani, 2013).

BBLR ialah bayi barn lahir yang berat badannya saat lahir kurang dari 2.500 gram (sampai dengan 2.499 gram). Berat Badan Lahir Rendah (BBLR) adalah bayi dengan berat badan kurang dari 2500 gram. Berat Badan Lahir Sangat Rendah (BBLSR) adalah bayi dengan berat badan lahir 1000 - 1500 gram. Berat Badan Lahir Amat Sangat Rendah (BBLASR) adalah bayi dengan berat badan lahir kurang dari 1000 gram. (Manggiasih, 2016).

Hal ini sejalan dengan penelitian yang dilakukan oleh Indrawati Siti di wilayah puskesmas minggir kabupaten sleman, yang menyatakan bahwa secara umum sesuai dengan berat bdan kehamilan, sementara wanita akan memiliki risiko tinggi mengalami lahir bayi BBLR, terutama jika ia tidak mampu untuk mendapatkan cukup berat badan selama kehamilan. Kelahiran prematur dan BBLR saat kehamilan merupakan masalah kesehatan masyarakat. Jadi kebutuhan nutrisi selama kehamilan lebih tinggi dari pada orang dewasa, karena mereka masih tumbuh tinggi dan kematangan fisik.

4. Hubungan Status Gizi Ibu Hamil dengan Kejadian BBLR

Pada penelitian ini status gizi diukur dengan LILA dengan hasil

KEK dan tidak KEK. Jika KEK $<23,5$ dan tidak KEK >23,5. Program di Rumah Sakit Dustira Tingkat II Kota Cimahi yaitu pemeriksaan LILA dan penyuluhan tentang gizi ibu hamil itu sangat penting untuk pertumbuhan dan perkembangan janin juga penting untuk ibunya dan memungkinkan tidak melahirkan bayi dengan BBLR.

Hal ini menunjukkan bahwa sebagian besar ibu bersalin yang mengalami tidak KEK dan yang mempunyai bayi BBLR sebesar 37 orang (68,5\%), sedangkan sebagian besar ibu bersalin yang mengalami KEK dan yang mempunyai bayi yang tidak BBLR sebesar 27 orang $(58,7 \%)$. Hampir sebagian ibu bersalin yang mengalami KEK dan yang mempunyai bayi BBLR sebesar 19 orang $(41,3 \%)$, sedangkan 
hampir sebagian ibu bersalin yang tidak mengalami KEK dan yang tidak mempunyai bayi BBLR sebesar 17 orang $(31,5 \%)$. Untuk mengetahui ada tidaknya hubungan yang signifikan antara status gizi ibu bersalin dengan kejadian BBLR dapat diketahui dari hasil uji statistik chisquare nilai $\mathrm{p}$ (signifikasi) yang didapatkan aaalah 0,006 yang berarti $\mathrm{p}<0,05$ maka Ho ditolak sehingga dapat disimpulkan bahwa "Terdapat hubungan antara status gizi ibu bersalin dengan kejadian BBLR".

Kekurangan gizi pada ibu hamil dapat mempengaruh proses pertumbuhan janin dan dapat menimbulkan keguguran, bayi lahir mati, kematian neonatal, cacat bawaan, anemia pada bayi, asfiksia intra partum (mati dalam kandungan), lahir dengan berat badan lahir rendah (BBLR). (Sukarni, 2013).

BBLR tidak hanya disebabkan oleh KEK saja tetapi ada faktor lain yang bisa menyebabkan BBLR seperti, umur kurang dari 20 tahun atau di atas 35 tahun, jarak hamil dan bersalin terlalu dekat, parita/jumlah anak yang terlalu banyak, Penyakit menahun ibu: hipertensi, jantung, gangguan pembuliih darah (perokok) (Maryunani, 2013).

Hal ini sejalan dengan penelitian yang dilakukan oleh (Indrawati \& Suratini, 2015), hasil penelitian menunjukkan bahwa terdapat hubungan antara status gizi ibu hamil dengan kejadian BBLR. Seorang ibu yang sering melahirkan memiliki resiko mengalami kurang zat gizi pada kehamilan berikutnya bila tidak memperhatikan kebutuhan nutrisi. Karena selama kehamilan zat gizi akan terbagi untuk ibu serta janin yang dikandungnya.

Hal ini sejalan dengan penelitian yang dilakukan oleh Nur'aini Siti Alifah tahun 2013 yang berjudul ibu hamil KEK berisiko melahirkan BBLR di puskesmas garung kabupaten wonosobo dengan hasil adanya hubungan antara ibu hamil berisiko KEK melahirkan BBLR $p$ value 0,000 .

Hal ini sejalan dengan penelitian yang dilakukan oleh Darmayanti Linda, yang menyatakan bahwa ibu hamil yang menderita KEK mempunyai kesempatan untuk melahirkan bayi BBLR 2,8 kali lebih besar dari pada ibu hamil yang tidak menderita KEK.

5. Hubungan Anemia Pada Ibu Hamil dengan Kejadian BBLR

Pada penelitian ini anemia dilakukan dengan hasil Hemoglobin. Jika $\mathrm{Hb}$ nya $<11 \mathrm{gr} / \mathrm{dl}$ maka dikatakan anemia dan jika $\mathrm{Hb}$ nya $>11 \mathrm{gr} / \mathrm{dl}$ maka dikatakan tidak anemia.

Program di Rumah Sakit Dustira Tingkat II Kota Cimahi yaitu pemberian tablet $\mathrm{Fe} 90$ tablet supaya tidak perdarahan pada saat kehamilan maupun persalinan dan supaya memungkinan tidak melahirkan bayi BBLR.

Berdasarkan hasil penelitian dapat diketahui bahwa sebagai besar ibu bersalin yang mengalami anemia dan yang mempunyai bayi BBLR sebesar 33 orang $(67,3 \%)$, sedangkan sebagian besar ibu bersalin yang mengalami anemia dan tidak mempunyai bayi tidak BBLR sebesar 28 orang $(54,9 \%)$. Hampir sebagian ibu bersalin yang mengalami tidak anemia dan mempunyai bayi BBLR sebesar 23 orang $(45,1 \%)$, sedangkan hampir sebagian ibu bersalin yang mengalami anemia dan yang mempunyai bayi tidak BBLR sebesar 16 orang $(32,7 \%)$. Untuk mengetahui ada tidaknya hubungan yang signifikan antara anemia pada ibu bersalin dengan kejadian BBLR dapat diketahui dari hasil uji statistik chisquare nilai $\mathrm{p}$ (signifikasi) yang didapatkan adalah 0,025 yang berarti 
p <0,05 maka Ho ditolak sehingga dapat disimpulkan bahwa "Terdapat hubungan antara anemia pada ibu bersalin dengan kejadian BBLR".

Anemia dapat didefinisikan sebagai kondisi dengan kadar $\mathrm{Hb}$ berada di bawah normal. Di Indonesia anemia umumnya disebabkan oleh kekurangan zat besi, sehingga lebih dikenal dengan istilah anemia gizi besi. Anemia defisiensi besi merupakan salah satu gangguan yang paling sering terjadi selama kehamilan. Ibu hamil umumnya mengalami deplesi besi sehingga hanya memberi sedikit besi kepada janin yang dibutuhkan untuk metabolisme besi yang normal. Selanjutnya mereka akan menjadi anemia pada saat kadar hemoglobin ibu turun sampai di bawah 11 gr/dl selama trimester III (Sukarni, 2013).

Kekurangan zat besi dapat menimbulkan gangguan atau hambatan pada pertumbuhan janin baik sel tubuh maupun sel otak. Anemia gizi dapat mengakibatkan kematian janin didalam kandungan, abortus, cacat bawaan, BBLR, anemia pada bayi yang dilahirkan, hal ini menyebabkan morbiditas dan mortalitas ibu dan kematian perinatal secara bermakna lebih tinggi. Pada ibu hamil yang menderita anemia berat dapat meningkatkan risiko morbiditas maupun mortalitas ibu dan bayi, kemungkinan melahirkan bayi BBLR dan prematur juga lebih besar (Sukarni, 2013).

BBLR tidak hanya disebabkan oleh juga anemia saja tetapi ada faktor lain yang bisa menyebabkan BBLR seperti, umur kurang dari 20 tahun atau di atas 35 tahun, jarak hamil dan bersalin terlalu dekat, Penyakit menahun ibu: hipertensi, jantung, gangguan pembuluh darah (perokok) (Maryunani, 2013).

Hal ini sejalan dengan penelitian yang dilakukan oleh Suhartati Susanti
(2016), yang menyatakan bahwa ada hubungan anemia pada ibu hamil dengan kejadian berat badan lahir rendah (BBLR) di wilayah kerja Puskesmas Tanta Kabupaten Tabalong. Hasil uji statistik dengan chi-square menunjukkan bahwa $\mathrm{p}$ $=0,000<0,05$ berarti Ho ditolak artinya adanya hubungan anemia pada ibu hamil dengan kejadian BBLR.

Hal ini sejalan dengan penelitian yang dilakukan oleh Linda Darmayanti, yang menyatakan bahwa ibu hamil yang menderita anemia mempunyai kesempatan untuk melahirkan bayi BBLR 1,05 kali lebih besar dari pada ibu hamil yang tidak menderita anemia.

\section{Kesimpulan}

Sebagian besar ibu bersalin mengalami KEK di Rumah Sakit dustira kota Cimahi Tahun 2018. Sebagian besar ibu bersalin mengalami kejadian anemia di Rumah Sakit Dustira Kota Cimahi Tahun 2018. Sebagian besar ibu bersalin mempunyai bayi BBLR di Rumah sakit Dustira Kota Cimahi tahun 2018. Terdapat hubungan antara status gizi dengan kejadian BBLR di Rumah Sakit Dustira kota Cimahi tahun 2018. Terdapat hubungan antara kejadian anemia dengan kejadian BBLR di Rumah Sakit Dustira Kota Cimahi tahun 2018.

\section{BIBLIOGRAFI}

Amareta, D. I. (2015). Hubungan Pemberian Makanan Tambahan-Pemulihan Dengan Kadar Hemoglobin Dan Kenaikan Berat Badan Ibu Hamil Kurang Energi Kronis (Studi Di Wilayah Kerja Puskesmas Jelbuk Kabupaten Jember). Jurnal Ilmiah Inovasi, 15(2).

Chairunita, C., Hardinsyah, H., \& Dwiriani, C. M. (2006). Model Penduga Berat Bayi Lahir Berdasarkan Pengukuran Lingkar Pinggang Ibu Hamil. Jurnal Gizi Dan Pangan, 1(2), 17-25. 
Dasar, R. K. (2013). Riskesdas 2013. In Jakarta Kementeri Kesehat Ri (Vol. 6).

Indrawati, S., \& Suratini, S. (2015). Hubungan Status Gizi Ibu Hamil Dengan Kejadian Bblr Di Wilayah Puskesmas Minggir Kabupaten Sleman. Stikes'aisyiyah Yogyakarta.

Manggiasih, F. N. (2016). The Use Of Quipper School As An E-Learning Platform In Teaching English To The Tenth Grade Students of Man 2 Ponorogo In Academic Year 2015/2016. Stain Ponorogo.

Manuaba, I. B. (2013). Keberadaan Dan Bentuk Transformasi Cerita Panji. Litera, 12(1).

Marmi, J., Martín-Closas, C., FernándezMarrón, M. T., Fondevilla, V., \& Gomez, B. (2015). A Riparian Plant Community From The Upper Maastrichtian Of The Pyrenees (Catalonia, Ne Spain). Cretaceous Research, 56, 510-529.

Maryunani, A. (2013). Perilaku Hidup Bersih Dan Sehat. Jakarta: Trans Info Media, 12(125), 20-37.

Nurbaiti, S. I. (2016). Pengaruh Pendekatan Problem Based Learning Terhadap Kemampuan Komunikasi Matematis Dan Motivasi Belajar Siswa (Penelitian Eksperimen Terhadap Siswa Kelas V Sdn Sindangjati Dan Sdn Bongkok Kecamatan Paseh Kabupaten Sumedang). Universitas Pendidikan Indonesia.

Roeslie, E., \& Bachtiar, A. (2018). Analisis Persiapan Implementasi Program Indonesia Sehat Dengan Pendekatan Keluarga (Indikator 8: Kesehatan Jiwa) Di Kota Depok Tahun 2018. Jurnal
Kebijakan Kesehatan Indonesia: Jkki, 7(02), 64-73.

Saifudin, A. (2014). Senyawa Alam Metabolit Sekunder Teori, Konsep, Dan Teknik Pemurnian. Deepublish.

Sibagariang, M., Lubis, Z., \& Hasnudi, H. (2010). Analisis Pelaksanaan Inseminasi Buatan (Ib) Pada Sapi Dan Strategi Pengembangannya Di Provinsi Sumatera Utara. Jurnal Agrica, 3(2), 104-112.

Silalahi, M., Walujo, E. B., Supriatna, J., \& Mangunwardoyo, W. (2015). The Local Knowledge Of Medicinal Plants Trader And Diversity Of Medicinal Plants In The Kabanjahe Traditional Market, North Sumatra, Indonesia. Journal of Ethnopharmacology, 175, 432-443.

Sucipto, P. T., Raharjo, M., \& Nurjazuli, N. (2015). Faktor-Faktor Yang Mempengaruhi Kejadian Penyakit Demam Berdarah Dengue (Dbd) Dan Jenis Serotipe Virus Dengue Di Kabupaten Semarang. Jurnal Kesehatan Lingkungan Indonesia, 14(2), 51-56.

Sukarni, I. (2013). Buku Ajar Keperawatan Maternitas. Medical Book.

Yuliati, Y., Pramiadi, D., \& Rahayu, T. (2014). Efektivitas Penggunaan Edutainment Konseling Gizi Terhadap Pemahaman Pemenuhan Gizi Seimbang Pada Remaja Putri. Jurnal Pendidikan Matematika Dan Sains, 2(2), 160-167. 